DOI :

\title{
Chinua Achebe's Objective Stance in Depicting Socio-Cultural Issues of the Igbo in the Novel Things Fall Apart
}

\author{
Md. Mahbubul Alam
}

Lecturer in English, Pabna Cadet College, Pabna, Bangladesh.

\begin{abstract}
In Chinua Achebe's magnum opus Things Fall Apart we see an authentic and objective presentation of the Igbo society. The ethnographic depiction of the Igbo life in the novel indicates that Achebe has tried to maintain his objective standpoint in dealing with various socio-cultural issues of the Igbo society. He has depicted these issues from the perspective of both an unbiased observer as well as an unprejudiced critic. The present study has shown to what extent and in which aspects has Achebe maintained his objective stance in depicting the pre-colonial Ibo society in respect of various socio-cultural mechanisms in the novel. To do so, firstly, this paper has presented the socio-cultural aspects like social administration, justice, respect for the elders, social status, rituals, communal harmony and unity etc. of the Igbo people in their real life already put forward by various researchers and anthropologists without considering the presence of their related contents in Things Fall Apart. Then, these real issues and their parallel presence in the novel have been presented side by side to see to what extent the scholars' claims about various socio-cultural sides of the Igbo life are either agreed or refuted in the novel. Finally, these issues are thoroughly dealt with to discuss Achebe's objectivity. The results show that the scholars' claim about the socio-cultural realities of the Igbo possesses close proximity with those of the novel. The core idea of the findings is that Achebe maintains objectivity in presenting various socio-cultural sides of the pre-colonial Igbo society in Things Fall Apart without spoiling any literary grandeur of the novel.
\end{abstract}

KEYWORDS: Chinua Achebe, Igbo people, Igbo society, objectivity, Things Fall Apart,

\section{INTRODUCTION}

It is rightly claimed that Chinua Achebe is the father of modern African literature (Aggarwal, 2013, p. 221). Many scholars have presented their arguments in favour of the claim. Such as, Gomba (2013) says, "The rise of Achebe has brought about the rise of many others, directly or indirectly" (p. 153). Ojaide (2013) states that Achebe's writings have contributed to "build a canon of modern African literature" (p. 150) and we see its true reflection in today's writers.

In his first novel Things Fall Apart the project Achebe adopts explains his position based on the interiority of original local contexts. Achebe has declared that he wrote the novel "in order to reassert African identity and as part of the growth of Nigerian nationalism" (O'Reilly, 2001, p. 61). Things Fall Apart has become the ambassadorial novel of the African continent. It shows the disintegration occurred in the Igbo's life once that was orderly, enriched and disciplined. In this respect, in his essay "Named for Victoria, Queen of England", Achebe (1995) expresses his moral responsibility to reassert the past. He said that Things Fall Apart "was an act of atonement with my past, a ritual return and homage of a prodigal son" (p. 103).

In his essay "The African writer and the English Language", Achebe argues that African literature should be defined as having "the complexities of the African scene" in material time, otherwise it is "doomed to failure" (1975, p. 75). Achebe presents to us an all-encompassing and meticulous depiction of the pre- colonial Igbo society in Things Fall Apart. One major purpose of his writing the novel is writing back to the Europeans or the colonizers who have long misrepresented Africa through their fabricated stories about Africa's longpracticed traditions and cultures. Prof. Fakrul Alam (2011) shares the same opinion: "One of Chinua Achebe's goals in writing Things Fall Apart was to correct a whole history of misrepresentations of his people and country in occidental discourse" (p. 5).

\section{DEFINING OBJECTIVITY IN LITERATURE}

There is debate whether works of fiction claim to represent the truth. There is a long history of reflection within critical theory on the relationship between art and the real, external 
world which it claims to represent, reflect, mirror, describe, etc. Lukács (1970) in his essay "Art and Objective Truth" seeks to grasp how a given work may objectively reflect the social totality of a given place and time in the process of change. In the work of art, "any extract, any event, any individual or any aspect of the individual's life must represent such a context in its concreteness, thus in the unity of all its inherent determinants" (p. 47). These determinants must appear as "concrete, direct, perceptible qualities of individual men and situations" (p. 48). According to Cuddon (2012), "Objectivity suggests that the writer is 'outside' of and detached from what he is writing about, has expelled himself from it, is writing about other people rather than about himself", and in this way the writer maintains 'negative capability' and 'aesthetic distance' (p. 690).

An objective or impersonal work is one in which the author presents the invented situation or the fictional characters and their thoughts, feelings, and actions and remains detached. An objective writer is free from bias in his writing. We can identify writer's bias. He makes assertions in his works and informs or persuades readers to believe a particular perspective. Consequently, he not only chooses the content of the work, he also chooses its tone. So, writer's bias can be found in content. We can examine the information the writer included or excluded in the text. Writer's bias can also be found in tone through an examination of the language used in the text.

The present study is now going to go through some major socio-cultural aspects depicted in the novel Things Fall Apart to analyze Achebe's objective stance.

\section{TEXTUAL ANALYSIS}

\section{Glorification of Masculinity}

According to Manus (2007, p. 255) and Nwoye (2011, p. $313)$, the Igbo society is highly patriarchal. The Igbo child is brought up in his father's lineage (Uchendu, 1965, p. 64). The father is an unquestioned authority in family; patriarchy and patrilineality form orders of authority and inheritance (Onyeozili \& Ebbe, 2012, p. 37). Nwoye (2011) says that women have no inheritance of land among the Igbo. In such cases the woman's male children inherit the land. In a word, masculinity controls the gender ideology amongst the Igbo. Kinship is primarily traced in the male line (p. 312).

Osei-Nyame (2009) expresses the view that "Achebe's text links and identifies power and authority with masculinity" (p. 4). We will study this report on the basis of Things Fall Apart. Okonkwo is the most prominent masculinist figure who appreciates Nwoye, his young son, when the later "would feign annoyance and grumble aloud about women and their troubles". He wants him to be like himself. He is always happy when he hears him grumbling about women. That shows that in time he will be able to control his women-folk. Okonkwo believes that a man may be prosperous but if he is unable to rule his women and his children, he is not really a man.
He also encourages the boys to sit with him in his obi and tells 'masculine stories of violence and bloodshed'. Okonkwo wants Nwoye "to grow into a tough young man capable of ruling his father's household when he was dead and gone to join the ancestors" (p.37).

In line with this, Jua (2009) claims that Things Fall Apart is a quintessential 'man' novel (p. 199) and 'It is the man, Okonkwo, who is privileged" (p. 201). This type of criticism of the text actually goes against Achebe who does not depict this masculinist picture intentionally. This is just a projection of social reality, not the reality created in the text.

\section{Individual Achievement and Status}

Personal achievement was mostly valued among the Igbo (Ohadike, 1996, p. xxvi). Igbo socialization processes are materialized on solid personal achievement. Asserting much importance to "individual achievement may account for the fact that the Igbo have been remarkably successful in a variety of professions" (Booker, 2003, p.110). Onyeozili \& Ebbe (2012) state that the people of Igboland "respected and honored achieved status more than ascribed status. Individual achievements determine a person's social position in his community. Consequently, alcoholism and loitering are not characteristics of the Igbo. They are very assertive and proud of their achievements, and they raise their children not to fail in life" (p. 31). The Igbo also value improving their status. They attach importance on individual social status. There is an Igbo proverb- "No one knows the womb that bears the chief" (Uchendu, 1965, p. 20, cited in Stevenson, 1985 , p. 14). The social status involves having a large progeny, wealth, effective leadership and generosity in helping other persons (Stevenson, 1985, p. 14).

The value of personal achievements is elaborately shown in Things Fall Apart. The protagonist, Okonkwo has no patience with unsuccessful men having no personal achievements. Okonkwo's "fame was rested on solid personal achievements" (p.3). There are frequent uses of the word 'failure' beside the name of Unoka, father of Okonkwo. Sometimes, Unoka's failure is contrasted to the success of other characters like Okonkwo and Okoye. Unoka is unsuccessful, has no acquired title, strength of arms, worldly determination and the socially ascribed manly qualities. Okonkwo is ashamed of his father having no manly achievements. "People laughed at him (Unoka) because he was a loafer" (p.4).

But Okonkwo is fortunate because "among these people a man was judged according to his worth and not according to the worth of his father." Okonkwo is the greatest wrestler in the nine villages. He is a wealthy farmer and has two barns full of yams, and has just married his third wife. He manifests great heroism in two inter-tribal wars. So, although Okonkwo is still young, he is already one of the greatest men of his time. (p.6) Age is respected among Okonkwo's people, but achievement is 'revered'. There is a proverb that if a child washes his hands he can eat with kings. Okonkwo has clearly 
washed his hands and so he eats with kings and elders (p.6). So, Owoyemi (2012) rightly observes that Okonkwo "started from scratch to become one of the leaders of his clan, through personal efforts" (p.177).

\section{Title}

The Igbo value titles. One of the personal achievements to the Igbo is acquiring titles. A titled man is a prestigious and powerful man in the clan. A man without title is called Agbala or 'women' and is buried 'without dignity' (Ohadike, 1996, p. xxvi). The highest title is Ozo (Ohadike, 1996, p. xxvi) and this title is the most prestigious (Nwoye, 2011, p. 306). Expensive initiation fees, elaborate feasting and dancing are required while taking the higher titles. To qualify for the highest title a man must also have acquired the junior titles and enough wealth. An $O z O$ man is no longer an ordinary man, but a god. (Ohadike, 1996, p. xxvi). The titleholders within the higher ranks enjoy some praise names such as, Ogbuefi (cow killer), Ogbuanyinya (horse killer), Ide (the piller) and Nze or chief. The signs of the titles include ankle cords tied on feet (owa $o z o)$, an iron staff (olo) and a cow or horsetail (nza) etc. (Nwoye, 2011, p. 306).

In Things Fall Apart the dignity of the title- holders is significant. Okoye is going to take the Idemili title, the third highest in the land (p. 5). Nwakibie has the highest title in the clan (p. 14). In the forest on the way to the place where Ikemefuna will be murdered the men heard the cheering and drum- beating of a title- giving ceremony in a nearby tribe. Ezeudu possesses three titles which "was a rare achievement. There were only four titles in the clan, and only one or two men in any generation ever achieved the fourth and highest. When they did, they became the lords of the land". (P. 87)

Ogbuefi is a title-holder's praise name that is found in the novel when Ndulue, once who was a great man and hero, is mentioned after his death. He is called 'Ogbuefi Ndulue' by the people. When he is no more his wife goes to his obi and calls by his name 'Ogbuefi Ndulue' three times. 'Ogbuefi' before the name 'Ndulue' suggests that he is a great titleholder, and was a strong man in his youth. We see the sign of title of Nwakibie carried by his first wife Anasi who wears the anklet of her husband's titles (14). There is Ogbuefi Ezeugo who is a powerful orator (8). There is Ogbuefi Udo whose wife is murdered by some men of the neighboring village Mbaino (ibid).

The Igbo expect and value the life that is full of achievements and glory. Acquiring titles is one of the achievements that the Igbo crave for. Craving for acquiring titles signifies a lot in Things Fall Apart. Through the description of the value of titles Achebe tries to show how ambitious and worldly the Igbo are. The psychology of a title-holder can be understood by the reader in the description. Throughout the text, we can easily distinguish a contrastive picture of the psychology and life of a title-holder and a non-title-holder, e.g., Unoka and
Okonkwo, or Unoka and Okoye. Achebe makes the contrast in order to convey the importance of titles to the Igbo.

\section{Obi and Ofo: Symbols of Achievement, Authority and Leadership}

The Igbo have the practice of architectural symbol of authority. Human-made structure, like the obi, indicates their notions of authority. The obi represents social, political, and economic principles and is seen as a social ideology of achievement and leadership. It is located at the centre of the family compound. Nwoye (2011) notes that the obi is the connecting point between the family space and external space- the inner familial reality and external social reality and "The central location of the $\mathrm{Obi}(\mathrm{Obu})$ in the family compound approximates in its structure Igbo notions of achievement and leadership" (p. 311). In the words of Ohadike (1996, p. XXIII), the most important lineage and house meetings were held in the obi of the most senior elders.

In Things Fall Apart we get significant reference to the obis of Okonkwo, Obirieka, Nwakibie and Uchendu. Each of the obis signifies distinct authority and possession of its owner. The narrator describes Okonkwo's obi-

Okonkwo's prosperity was visible in his household. He had a large compound enclosed by a thick wall of red earth. His own hut, or obi, stood immediately behind the only gate in the red walls. Each of his three wives had her own hut, which together formed a half moon behind the obi. (p.10)

In Mbanta Okonkwo with the help of his mother's kinsmen builds himself an obi and three huts for his wives (p.91). When Oknokwo with a pot of palm-wine and a cock goes to Nwakaibie to borrow seed-yams, he meets him in his obi (p.14). Whenever Okonkwo meets Obierika in the latter's house his obi is the common place. The repeated use of obi in the novel suggests that it attempts to unfold a reality of allpervasive masculine ideology of Igbo society.

Ofo is one of the ritual symbols of authority among the Igbo. It is, to the Igbo, the supreme ancestral symbol, the staff of traditional influence. It is also the symbol of justice and truth. The oldest person of the lineage or family holds the Ofo. It is handed down from generation to generation (Nwoye, 2011, p.315). An Ofo is obtained from the twig of the ofo tree (Nwagbara, 2011, p. 143).

Things Fall Apart has a very little reference to Ofo. Only once throughout the whole text the reference to Ofo occurs and it is when Uchendu, Oknokwo's maternal uncle and the oldest member in his surrounding, sits together with his family members at the occasion of his son's marriage. The narrator describes the situation-

They sat in a big circle on the ground and the bride sat in the centre ... Uchendu sat by her, holding the ancestral staff [ofo] of the family. (P. 93) 


\section{No King, Police or Modern Administration}

Chowdhury (2012) in a book about African myths states, "The extent of belief surpasses the material world to the metaphysical world- the integration of which makes social harmony in African rural life possible where there is no scope for any centralized authority" (p.21) (My translation from Bangla). In Igboland too there is no scope for any centralized authority. Igbo society lacks the centralized political structure (Ohadike, 1996, p. XXII; Nwoye, 2011, p.305). The Igbo have been described as The King in Every Man (Henderson, cited in Onyeozili and Ebbe, 2012, p.30) which means that the Igbo have no kingship system. Though they have no centralized government or king with power, they abide by laws before the coming of European influence (p.38). Onyeozili \& Ebbe (2012) argue that in Igboland "social control was informal but efficient. There was no formalized police system in modern sense of the words" (p.35). Majumder (2007) refers to Ram Nath, an Indian tourist and writer who had practical experiences about African societies and says, "Ram Nath did not see any police in the villages, nor did he feel its necessity" (“Ouponibeshik Bonam” (p.139).

The world of Things of Apart is a world of no king or central power. The missionaries ask the villagers who the king of the villagers is. But the villagers tell them that there is no king. They say to the missionaries, "We have men of high title and the chief priests and the elders" (p.105). Majumder (2007) refers to Tyler, an anthropologist, whose writing is thought to be objective. Tyler writes-

The tourists, after reaching the impassable countries [in Africa] and seeing no police system available in their own countries, come to the direct conclusion that the cannibals live there as their wishes. We think it is a wrong belief, because, in these 'uncivilized' countries there are severe rules and regulations in each stapes of life. ("Ouponibeshik Bonam", p. 137) (My translation from Bangla)

One noteworthy point is that though there is no king in Igboland, the Igbo people are not completely ignorant of the concept of kingship. They may have no first- hand experiences of kingship but they have idea about the grandeur of kingship. Things Fall Apart mentions a proverb that is related to king"If a child washed his hands he could eat with kings" (p.6). This proverb tells us that the Igbo are well aware of the height and honor of a king.

Similarly, Things Fall Apart deals with a society where people live by abiding by traditional laws, rules and regulations. It is not that the society depicted in it is free from vices and crimes. There are evil doers as well as punishment ascribed by socio- cultural rules. That is why there is no need for the police system or other formal tools for social security. This system prevails until European colonialism comes.

\section{Restorative Justice}

Justice in Igboland conforms to restorative justice.
Restorative justice, according to Mediation $U K$, is "a process whereby victims, offenders, and communities are collectively involved in resolving how to deal with the aftermath of an offence and its implications for the future" (cited in Omale, 2006, p.36). According to Merry, the main task of traditional dispute settlement in Africa is to 'restore social harmony' and 'reconcile the parties'. So, the penalties generally focus on compensation or restitution in order to restore the status quo, rather than punishment. (Cited in Omale, 2006, p.45) Elechi (cited in Omale, 2006, p. 37) reviews widely the restorative traditions of dispute resolution amongst the Igbos. Onyeozili \& Ebbe (2012), for example, say about the offender who has to accept exile-

In cases of abominable hateful offenses like murder, an offender and his family may be permanently expelled from the community. If the offense is manslaughter- an unintentional murder, the resultant penalty would differ. The guilty person and all his family are required to go on exile for a given number of years after which they would be reconciled with the community. (p.37)

But, homicide is strictly forbidden to the Igbo. "Spilling the blood of a townsman or townswomen was a serious offence against the earth goddess... If a murder occurred in precolonial times, certain age-groups mightseize the property of the murderer and destroy his house" (Ohadike, 1996, p. XXXVII). In the funeral ceremony of Ezeudu, Okonkwo's gun explodes and the dead man's sixteen year old boy is killed. It is an unintended killing. But Okonkwo is not out of danger. He has to accept punishment and he does so.

The only course open to Okonkwo was to flee from the clan. It was a crime against the earth goddess to kill a clansman, and a man who committed it must flee from the land. The crime was of two kinds, male and female. Okonkwo had committed the female, because it had been inadvertent. He could return to the clan after seven years. (P.88)

The justice delivered on Okonkwo's case is restorative in nature. The punishment does not destroy Okonkwo's life. Only he has to renew the life after leaving his original land for seven years. The justice gives chance to him for his regeneration in Mbanta. A cow has been let loose during the Uri ceremony of Obierika's daughter. The cow is driven back to the owner "who at once paid the heavy fine which the village imposed on anyone whose cow was let loose on his neighbor's crops" (p. 81). This event shows how law- abiding the Igbo are. Justice is done when the cow is given back to the owner. The incident too indicates restorative justice in Igboland.

One significant thing is that we do not see any prison or asylum in the Igbo society depicted in Things Fall Apart, as we see in the modern world. Nor do we see any trace of Panopticon (my italic). The Panopticon is a type of institutional building designed in the late 18th century. It allows a single watchman to observe (-opticon) all (pan-) inmates of an institution 
without the inmates being able to tell whether or not they are being watched. According to Foucault, "the Panopticon is an architectural design or plan that signals a convergence of a historically situated political and social ideology, a sociomaterial epistemology, and a pragmatics of social control and resistance. In its most concrete form, the Panopticon is a socio-material template for institutional orders of all kinds ranging from prisons, to schools, to factories, to hospitals." (Simon, 2005, p.2) In the Igbo society there is no system of prison, the existence of the Panopticon is beyond question. Rather, it is by the Western colonial authority, represented by the District Commissioner, the system of prison and surveillance is introduced. At the end of the novel, Okonkwo and the leaders of Umuofia are tortured by the Colonial administration. This type of torture is quite unknown to the people of Umuofia.

\section{Decision Making}

In traditional or non-literate societies there are attempts to take public decision and dialogue and try to avoid war. Udefi (2012) observes that, in the time of an impending war people rise up to look for solutions and strategies to either avoid or prosecute the war. The decision is arrived at through 'critical dialogue' (p.62). Ezenweke et al (2013) agree with Udefi and opine that the African concept of democracy contained in her philosophy of republicanism is deeply rooted, for example, in Igbo life and thought. Before taking any decision the people have the tradition of gathering together to discuss matters in order to arrive at an agreement (p.66).

Things Fall Apart witnesses that Umuofia "never went to war unless its case was clear and just and was accepted as such by its Oracle- the Oracle of the Hills and the Caves". In some certain occasions the Oracle forbids them to enter into war (p.9). When a woman of Umuofia is killed by some men of the neighboring village Mbaino, the people do not take any decision of attacking that village. They offer options- "at the end it was decided to follow the normal course of action. An ultimatum was immediately dispatched to Mbaino asking them to choose between war on the one hand, and on the other, the offer of a young man and a virgin as compensation." (P.8)

When three converts kill the sacred python the people of Mbanta decide to keep patience, though the killing of the sacred python is similar to the killing of god. In the meeting it is said-

It is not our custom to fight for our gods...let us not presume to do so now. If a man kills the sacred python in the secrecy of his hut, the matter lies between him and the god. We did not see it. If we put ourselves between the god and his victim we may receive blows intended for the offender, when a man blasphemes, what do we do? Do we go and stop his mouth? No. We put our fingers into our ears to stop us hearing. That is a wise action. (P.113).

Everybody in the assembly speaks. In the end it is decided that the Christians must be ostracized. These two events are enough to show that the Igbo always try to avoid war. Whatever they want to do for their community purpose they do it through public decision. There is no decision that is not representative of the whole clan.

\section{Secret Society}

There are secret societies in Igboland who work for maintaining peace and order if the individuals themselves are incapable of doing so. Some secret societies are exclusively for men, some for women, and others for the both. The members of this society took their 'oath of secrecy' that is why very little was known about it. They are called egwugwu and use masks in the judicial process. According to Achebe (1975), the masked spirits are "representative visitors" from the underworld (p.134). They are "the mouthpieces of the ancestors, oracles, and spirits". The egwugwu as masked ancestors appear in important legal matters and pronounce the verdict. No one can deny their judgment, because no one is wiser than the ancestors. No one discloses the identity of the man behind the mask, even if he happens to identify the voice or the walk of a particular familiar man. (Ohadike, 1996, p. XXX)

In Things Fall Apart each of the nine villages of the clan has a representative egwugwu whose leader is called Evil Forest (p.66). The egwugwu house faces the forest. People can see only its back. Even the women who decorate the egwugwu house never see the inside of it. If they imagine what is inside, they keep their imagination to themselves (p.63). Okonkwo represents his village in the committee of egwugwu. About an event of solving judicial matters where Okonkwo is present among the egwugwu the narrator describes-

Okonkwo's wives, and perhaps other women as well, might have noticed that the second egwugwu had the springy walk of Okonkwo. And they might also have noticed that Okonkwo was not among the titled men and elders who sat behind the row of egwugwu. But if they thought these things they kept them within themselves. The egwugwu with the springy walk was one of the dead fathers of the clan. (P. 64)

This description indicates that the identity of the members of the egwugwu is kept secret. The judicial meeting is about several problems. Among them is the dispute between Uzowulu and his wife. In this trial process Evil Forest, the chief egwugwu, says,

We have heard both sides of the case. Our duty is not to blame this man or to praise that, but to settle the disputes. (P.60) This indicates the validity and reliability of the judgment delivered by the egwugwu. Evil Forest orders Uzowulu-

Go to your in- laws with a pot of wine and beg your wife to return to you. It is not bravery when a man fights with a woman.

Then he orders Odukwe, the brother of Ezowulu's wife- "If your in-law brings wine to you, let your sister go with him". 
Again, the judgment of the egwugwu clearly reflects the fact that Igbo judgment is restorative; it is constructive, rather than destructive. The egwugwu could have separated the family to solve the conjugal problem permanently. Instead, by delivering restorative verdict they try to establish reunion between the husband and the wife.

\section{Respect for Elders}

The Igbo respect their elders. They say that he who listens to an elder is like one who consults an oracle and they are teacher and director of the young (Ezenweke \& Nwadialor, 2013, p. 67). Young people follow the elders for both of the material and the immaterial worlds.

Okonkwo calls Nwakibie, who helps him by giving eight hundred seed yams, 'Our father'. He says to him, "As our people say, a man who pays respect to the great paves the way for his own greatness" (p.14). Even seniority is maintained among the departed ancestors. In the egwugwu meeting Evil Forest is the leader. At the beginning of the trial process the egwugwu take their respective seats. The Evil Forest "took the first of the empty tools and the eight other egwugwu began to sit in order of seniority after him" (p.63).

\section{Organic Society}

In an organic society all of its structures work together in a balanced way. Igbo society is an organic one since its component parts are balanced and work in a complex web of actions. Duarte referring to Diana Akers Rhoads (cited in Bandyopadhay, 2012) notes that Igbo society "achieved what most people today search: democracy, tolerance, balance of male and female principles, adaptability to changing circumstances, redistribution of wealth, effective systems of morality and justice, and memorable poetry and art".

Chinua Achebe's Things Fall Apart is an excellent model of portraying a balanced society. The society presented in the novel is coherent in its structure. It has a peculiar and distinct identity with which its members are identified. This society as depicted in the novel consists of a "collectively shared vision of life that is reinforced by accumulation of wisdom and experience" (Maleki \& Navidi, 2001, p. 12). The people of Umuofia and Mbanta collectively contribute to the organic identity of their clans. That is why smooth running of the society has been possible without having any central political and administrative authority.

In discussing the organic quality of 1 the Igbo society Aristotle's concept of Polis is worth mentioning. Aristotle, in the Politics, sought an ideal society for people to live in and the polis may become that ideal society. According to Aristotle, the polis must attain three main goals: a manageable population, stability through effective rule, and self-sufficiency towards essentials. The population must be stable in the polis. All the people of a polis must share both advantages and disadvantages of each other because they realize that they need each other to survive. The polis is some kind of bond of brotherhood and communal harmony. Stable governance is a major component in the polis in order for making sure that all parts of the community run smoothly. Self-sufficiency should be the highest priority in the polis. A polis has to be able to stand on its own two feet.

In Things Fall Apart, the society depicted can be compared to the Aristotelian polis. But, unlike in polis, we are not sure whether the population in the Igboland is manageable, because, on the one hand, most of the families here are polygamous creating immense scope for over-population, and on the other hand, the Igbo society is economically, politically and culturally so self-sufficient that it seems that over-population creates no problem. But, like the people of the polis, the people of Igboland exercise the sense of brotherhood and collective feelings that will be discussed in the related field of this paper. Like the polis the governance system in Igboland in the novel is stable and competent. This issue has already been discussed in the previous section of this paper. And, lastly, that the Igbo society is self-sufficient both in economy, politics and culture is frequently indicated in this paper. So, we can draw a strong parallel between Aristotelian polis and the Igbo society presented in Things Fall Apart.

\section{Communal Harmony and Unity}

Community and culture are interwoven. Ngugi wa Thiong'o (2004) shows how culture evolves through communal harmony-

In doing similar kinds of things and actions over and over again under similar circumstances, similar even in their mutability, certain patterns, moves, rhythms, habits, attitudes, experiences and knowledge emerge. Those experiences are handed over to the next generation and become the inherited basis for their further actions on nature and on themselves. There is a gradual accumulation of values which in time become almost self-evident truths governing their conception of what is right and wrong, good and bad, beautiful and ugly, courageous and cowardly, generous and mean in their internal and external relations. Over a time this becomes a way of life distinguishable from other ways of life. They develop a distinctive culture and history. (p. 1133, 1134)

When Europe came in contact with Africa in the middle of the fifteenth century, African societies were tribal and feudal. Those societies were yet to be acquainted with the sense of self- ownership and capitalism since they were selfindependent. The tribes were guided by strong sense of collectivity, duty, and morality (Elias, 2004, p. 168). For the African man, the basic belief is "I am because we are". Uzukwu states: "one is human because of others, with others, and for others, and since we are therefore I am. I belong therefore I am" (cited in Ezenweke et al, 2013, p.64). These statements prove that collectivity and communal feelings are the essence of African culture. 
Igbo culture is built on a strong sense of devotion to community (Booker, 2003, p. 110). For Ifemesia (p.70), "interdependence is a fundamental principle of Igbo philosophy of life because a tree does not make a forest" (cited in Ezenweke et al, 2013, p. 64). The Igbo ideology of interdependence signifies that unity is strength and it promotes discipline, reduces crime and humanizes relations (Ezenweke et al, 2013, p. 64) and "Life in African Community is based on the philosophy of live-and let-live" (p.65).

The society in Things Fall Apart is a society of communal harmony and cooperation. There are various festivals that are great occasions of expressing communal feelings. In the novel we notice that people are cooperative to each other. Okonkwo in his earlier life went to Nwakibie to borrow seedyams. At that time the elders had doubt about sincerity in the young generation. But Nwakibie helped him by giving him eight hundred seed-yams. (P.15)

When Okonkwo is exiled for seven years he takes shelter in his maternal uncle's house. All the people help him resume his life. In Mbanta at his maternal uncle's house Okonkwo is given a plot of ground where he builds his compound. He is also given some pieces of land for farming during the coming planting season. His mother's kinsmen help him build an obi for himself and three huts for his wives. Each of his uncle's five sons contributes three hundred seed-yams to plant a farm. (P.91)

The festivals elaborately mentioned in the novel strongly signify the collective and cooperative facets of the Igbo. Any festival of a family is not limited to that family only; it is the festival of the whole clan. We see such a festival during the marriage of Obierika's daughter. The whole village turns into a single family to observe the marriage ceremony. Each of the villagers thinks the ceremony as his/ her own. The narrator describes-

As soon as day broke, breakfast was hastily eaten and women and children began to gather at Obierika's compound to help the bride's mother in her difficult but happy task of cooking for a whole village. (P. 78)

Things Fall Apart manifests that the collective communal feeling in Igboland works not only in the time of happiness, it is also active in sufferings and sorrows of anybody of the clan. All the people are caught up with each other. If anybody does something heroic it goes to the credit and joy of the whole clan; if anybody does something shameful or abomination it also affects the whole clan. Okonkwo's life- history justifies this point.

Okonkwo is the representative figure of his community. Okonkwo's individual crisis and the crisis of the community have close relationship (Gikandi, 1996, p. X). There is no appreciation of the heroic existence in Okonkwo, but the clan's heroic existence is his own heroic existence. His life form is interwoven with that of his society; apart from this he does not believe in any other ideas, thoughts, or existence. (Majumder, 2004, p. 208).

When Okonkwo in his young age won the wrestling, the whole clan becomes the winner. Again, when he commits an unintentional offence, the whole community feels guilty and afraid of the gods' wrath. For example, Umuofia shares a collective guilt of killing Ikemefuna (Coker \& Coker, 2008, p. 23). Related to the collective existence of the people of Igboland is magara. Magara is the collective life force of the whole clan. Ikemefuna's death will restore the magara lost by the clan when one of its daughters, who would have brought more descendents into its life, strengthening the magara of the clan, was killed. The clan suffered the loss of the woman and the children she could have produced. (Benoit, 1980, p.39).

Sentinaro and Chandra (2009) have rightly observed that the central character of Things Fall Apart is not Okonkwo but Umuofi where "society wins over an individual in the Ibo society" (p.192). This indicates that the society as a whole stands for the individual's existence. It also signifies that the people of Umuofia stand for essential unity. There is no individual character; all the Umuofians are a singular entity.

\section{CONCLUSION}

Chinua Achebe in his literary works always maintains authenticity irrespective of whether the issues to be dealt with possess positive or depressing implications. His approach is never romantic or propagandist (O'Reilly, 2001, p. 34). This is true for Things Fall Apart in which we observe a bona fide presentation of Umuofian society before the devastating knock of colonial power at the door of Umuofiua. The text is written in the language of the colonizer, but it is, as Strong-Leek says, 'authentically African' (p.30). The project Achebe regulates in Things Fall Apart is the perspective of external observation (Irele, 2000, p.3) and 'Igbo autoethnographic self- representation' (Bandyopadhyay, 2012). On the whole, he is an insider of the context but this identity cannot contaminate his neutrality as a writer. Throughout the novel he illustrates "truthful and detailed picture of Igbo society and culture" (Maleki \& Navidi, 2001, p. 13) and never deviates from this enterprise of conviction.

\section{REFERENCES}

1. Achebe, C. (1975). Morning Yet on Creation Day. New York: Heinemann.

2. Achebe, C. (1995). Named for Victoria, Queen of England. In: B. Ashcroft et al (ed.), The Post Colonial Studies Reader (pp.190-193). London: Routledge.

3. Achebe, C. (1996), Things Fall Apart. Johannesburg: Heinemann.

4. Aggarwal, R, (2013), Chinua Achebe's 'Things Fall Apart'; colonialism versus tradition. Indian Journal of Applied Research, 3 (4), 221- 222. 
5. Alam, F, (2011), Reading Things Fall Apart Ecocritically. Metropolitan University Journal, 3 (1), 10-16.

6. Bandyopadhyay, K. (2012). When Things Came Together: a book about a book. The Daily Star, 22 September 2012.

7. Benoit, J. (1980). Archetypal Patterns Underlying Traditional African Cultures: Janheinz Jahn's Muntu and Chinua Achebe's Things Fall Apart. Contributions in Black Studies, 4 (1), 35-42.

8. Booker, M. K. (2003). (Ed.) The Chinua Achebe Encyclopedia. Connecticut: Greenwood Publishing.

9. Coker, A. and Coker, O. (2008). Thematic Significance of Indigenous Legal Regime in Chinua Achebe's Things Fall Apart. IRWLE, 4 (2), 20- 26.

10. Chowdhury, S. (2012). Africar Myth. Dhaka: Barnayan.

11. Cuddon, J. (2012). Dictionary of Literary Terms and Literary Theory. New Jersey: John Wiley.

12. Elias, K. (2004). Uponibeshbad: African- Caribbean ebong African- American Prekhshit. In: Sibnarayan and Shamim (ed.) Africar Sahityo Songroho- 2 (pp.167-172). Dhaka: Kagoj Prokashon,.

13. Ezenweke, E. et al. (2013). Understanding Human Relations in African Traditional Religious Context in the Face of Globalization: Nigerian Perspectives. American International Journal of Contemporary Research, 3 (2), 61-70.

14. Gikandi, S. (1996). Chinua Achebe and the Invention of African Literature. In: Things Fall Apart. Johannesburg: Heinemann.

15. Gikandi, S. (2001). Chinua Achebe and the Invention of African Culture. Research in African Literatures. 32 (3). 03-08.

16. Gomba, O. (2013). Tribute: Things still apart: Chinua Achebe's whetstone. Tydskrif vr Letterkund, 50 (2), 152157.

17. Irele, F. (2000). The Crisis of Cultural Memory in Chinua Achebe's Things Fall Apart. Africa Studies Quarterly, 4 (3), 01- 40.

18. Jua, R. (2009). Things Fall Apart and Achebe's Search for Manhood. Interventions, 11 (2), 199-202.

19. Lukacs, G. (1970). Art and Objective Truth. In: K. Arthur (ed.), Writer and Critic and Other Essays (pp 25-60), Grosset \& Dunlap.

20. Majumder, S. G. (2004). Golper Varsammer Khuje. In: Sibnarayan and Shamim (ed.). Africar Sahityo Songroho2 (pp. 201- 219). Dhaka: Kagoj Prokashon, pp. 201- 219.

21. Majumder, S. G. (2007). Africa: Ouponibeshik Bonam Uponibeshiter Chukhe-Prekhshit: Ram Nath Bishwasher
Ondhokarer Africa. In: C. Fakrul (ed.) Uponibeshbad O uponibeshik Path 9 (pp.127- 141). Dhaka: Raman Publishers.

22. Maleki, N. and Navidi, M. (2001). Foregrounding Achebe's Things Fall Apart: A Postcolonial Study. Canadian Social Science, 7 (6), 10-15.

23. Manus, U.C. (2007). The Sacred Festival of Iri Ji Ohuru in Igboland, Nigeria. Nordic Journal of African Studies, 16(2), 244-260.

24. Nwagbara, E. N. et al . (2011). The Sociological and Human Rights Implication of Ostracism: The Case of Osu Caste in The Igbo Ethnic Group of Nigeria. African Journal of Social Sciences, 1 (2), 140-151.

25. Nwoye, C. (2011). Igbo cultural and religious worldview: An insider's perspective. International Journal of Sociology and Anthropology, 3(9), 304-317.

26. Ohadike, D. C. (1996). Igbo Culture and History. In: Things Fall Apart. Johannesburg: Heinemann.

27. Ojaide, T. (2013). Tribute: Chinua Achebe. Tydskrif vir Letterkunde, 50 (2), 150- 151.

28. Okodo, I. (2012). African traditional drama: the IgboNigerian experience. Journal of Emerging Trends in Educational Research and Policy Studies, 3 (2), 131-136.

29. Omale, D. J. (2006). Justice in History: An Examination of 'African Restorative Traditions' and the Emerging 'Restorative Justice' Paradigm. African Journal of Criminology \& Justice Studies, 2 (2), 33- 63.

30. Onyeozili, E. C. and Ebbe, O. N. I. (2012). Social Control in Precolonial Igboland of Nigeria. African Journal of Criminology and Justice Studies, 6 (1\&2), 29- 43.

31. O’Reilly, C. (2001). Post-Colonial Literature. New York: Cambridge University Press.

32. Osie- Nyame, K. (2009). Achebe's Writing Culture: Representations of Gender and Tradition in Things Fall Apart. In: H. Bloom (ed.). Chinua Achebe's Things Fall Apart (5-22). New York: InfoBase Publishing.

33. Rao, C. N. (2007). Sociology. New Delhi: S. Chand \& Company Ltd.

34. Sentinaro, I. and Chandra, N. D. R. (2009). Culture as Reflected in Achebe's Works and Ao Naga Literature. Journal of Literature, Culture and Media Studies, 1(2), 188- 199.

35. Simon, B.(2005). The Return of Panopticism: Supervision, Subjection and the New Surveillance. Surveillance \& Society, 3(1), 1-20.

36. Stevenson, I. (1985). The Belief in Reincarnation among the Igbo of Nigeria. Journal of Asian and African Studies, XX (1-2), 13-30. 
37. Strong-Leek, L.(2001). Reading as a Woman: Chinua Achebe's Things Fall Apart and Feminist Criticism. African Studies Quarterly, 5 (2). 29-35.

38. Thiong'o, w. N. (2004). Decolonising the Mind. In: Julie R and Michael R (ed.) Literary Theory: An Anthology (pp. 1126-1150). Oxford: Blackwell Publishing.
39. Uchendu, V. C. (1965). The Igbo of Southeast Nigeria. New York: Holt, Rinehart and Winston.

40. Udefi, A. (2012). Philosophy, Mythology and an African Cosmological System. Global Journal of Human Social Science, Geography \& Environmental Geosciences, 12 (10), 59- 63.

Citation: Md. Mahbubul Alam, “Chinua Achebe's Objective Stance in Depicting Socio-Cultural Issues of the Igbo in the Novel Things Fall Apart", American Research Journal of English and Literature, Vol 7, no. 1, 2021, pp. 1-9.

Copyright (C) 2021 Md. Mahbubul Alam, This is an open access article distributed under the Creative Commons Attribution License, which permits unrestricted use, distribution, and reproduction in any medium, provided the original work is properly cited. 